attain fulfilment! Brink makes a second attempt at the tandem of the older man with a waning libido and the desirable young woman in Before I Forget. In an effort to make up for his failure to possess Rachel, Chris Minaar makes us accompany him through his own personal, nostalgic journey to the past of women galore and an ever reliable member. In Slow Man, Paul Rayment's infatuation with his Croatian day nurse foreshadows the relationship between Anya and Mr C. Rayment's accident forces him into a situation of physical dependency which develops into emotional dependency. Mr C's contracting Anya's services is a deliberate act that springs from the desire she provokes in him, her presence too taking the guise of an obsession. Unlike Brink's Chris Minaar, Mr C does not regale us with a Don Juan-like account of his conquests. In fact, we learn surprisingly little of the erotic cavorting of his younger days. But $\mathrm{MrC}$ reveals to us like none of the other protagonists of the fore-mentioned works the frustration of feeling the stirrings of youth in one's blood stymied by the failings of a decrepit body. "I seem to have grown obsessed, to the extent that a man can be called obsessed when the sexual urge has dwindled and there is only a hovering uncertainty about what he is actually after, what he actually expects the object of his infatuation to supply" (89).

A wordmonger of Coetzee's stature dispels any doubts that may prevail among those who cannot conceive of verbal fineries produced in what they persist in viewing as the backwater of the metropolis: the ex-colonies. He continues to whittle his sentences down to the most essential combination of subject predicate, discarding cumbersome modifiers. Having shed all excessive fat, the bone of Coetzee's prose has only the choicest lean adhering to it. He always produces the sensation that concepts acquire a more profound import thanks to the aptness of the words with which they have been posited. Similarly with Coetzee's strong opinions! Regardless of whether we, like Anaya, hesitate to agree with them, we are sucked into his train of thought by the preciseness and clarity of his exposition. Could anything less be expected from a literary master and Nobel Prize winner? The excellence of the prose, especially that employed in the opinions section, inclines the reader to conclude that Diary of a Bad Year is more than just yet another novel about an elderly gentleman fantasizing about a younger woman.

\title{
Orígenes del feminismo: Textos ingleses de los siglos XVI al XVIII. Ed. Lidia Taillefer De Haya Madrid: Narcea, 2008. 256 pp.
}

Reviewed by Rosa Muñoz Luna

University of Málaga

Orígenes del feminismo is a ground-breaking volume which compiles not only feminist names but also social and historical contexts that back up women's (re)actions throughout history. Focusing on the period that goes from the sixteenth up to the eighteenth century, its novelty lies on its intimate narrative tone, and on its bringing to scene original texts mostly unknown for the Spanish speaking public.

Once more, Lidia Taillefer offers us new insights into the world of Gender Studies; in this case, these are related to the origins of feminist thinking through the presentation of almost unknown documents written five hundreds years ago. This complete and reader-friendly volume collects texts written by women who were pioneers in the world of Linguistics and Education, and who vindicated their democratic rights by using their written force. Their 
writings can be divided into two groups: those published in response to sexist pamphlets and to discriminating pieces included in some literary works of the time; and, on the other hand, fragments dealing with the description of daily routines in the authors' lives, which also illustrate the working and familial situation of those women. These collected writings are within each author's personal and professional spheres, what results in a more intimate and revealing work regarding the situation in which the protagonists lived at that time. The book satisfies the objectives initially set by the editor in her Introduction: these pages help to understand both the origin and the evolution of feminism as a liberating movement and as a way of living, particularly in seventeenth-century England.

Only a few years ago, Valle Ferrer (2006) and Fields (2003) also made public the most private and unknown side in the lives of some pioneering feminists with publications on outstanding women figures (The Story of Luisa Capetillo, a Pioneer Puerto Rican Feminist and Katherine Dexter McCormick: pioneer for women's rights, respectively). Their common focus on American social movements contrasts with that of Mabel Dove (2004), whose ground-breaking findings on West African feminism have been edited recently by Newell and Gadzekpo in an influential volume that sheds light on this research field not very much studied so far, and which is entitled Selected Writings of a Pioneer West African Feminist. Interestingly, these three volumes share the same intimate tone that is also present in Taillefer's. Suffragists and female rule-breakers had been previously presented as political figures, leading names at the beginnings of the twentieth century that laid the foundations of gender equality and freedom; in this case, the latest publications on the gender arena bring to light the most human and familiar face of those women, making their stories and principles closer to the reader and thus easier to be shared and understood.

However, in opposition to other works, Taillefer's publication offers not only new literary material but also the fact that all characters in the book are British feminists. Both in the United Kingdom and in the United States, and due to the existence of Women's Studies Departments since the second half of the twentieth century, the publications of writings in defense of women throughout history have been prolific. Nevertheless, former titles published in those countries mix writings of female authors from different nationalities and when they focus on English-speaking names, they tackle both English and American writers indistinctively. Dr. Taillefer's work presents, for the first time, a remarkable study that is specifically focused on British female authors.

A precise and readable manual like this offers wide margins, clarity in the printing, a manageable layout and covers that make the reading process very pleasant. As a visual support for a better understanding of the historical context, Orígenes del feminismo starts with a chronological chart that goes from 1558 up to 1799. This graph is a detailed collection of the main events that have influenced the feminist evolution in Europe, with special attention to France, England and Italy. Previous works on the field normally take us back no more than three centuries in time, being Mary Wollstonecraft always their starting point. In this case, we find fifteen other names (mind there are two authors in Chapter 3), most of them unknown for the Spanish public, who date back to the sixteenth and seventeenth centuries. The historical revision of this book begins in 1558, when Queen Elizabeth came to throne, being the following years a flourishing period regarding culture; she was into the world of translation and linguistics, and Taillefer, always interested in women's duties in the academic scene, brings into play this ancient figure as one of the first promoters of women's scholarly careers (for more information on pioneering female linguists in England see Taillefer's "Pioneras de 
la lingüística inglesa: traductoras, educadoras y lingüistas" (2007b)). Some time later, as shown in the chart, Margaret T. Tyler published a preface of elegant feminist spirit in one of her translations focused on chivalry novels. Her example was followed by many other men and women in the subsequent years, establishing solid bases for powerful feminist trends in the future. Among them, the publication of political brochures stand out because of their demands in favour of women's rights as an active answer to other misogynic leaflets published before; a relevant instance of this feminist reaction is Rachel Speght's reply to the famous The Arraignment of Women, published by Joseph Swetnam in 1615.

On a more sociological basis, this chronological table also includes the dates of the wars that were fought at that time, and that deeply affected the course of history. The First and the Second English Civil Wars led the country into a decade of uncertainty and fear where there was little room and less political strength for the female fields of letters. During the Stuart monarchical restoration and in an atmosphere of increasing stability, some women's publications fell into the hands of privileged high-class readers. The diffident tone of those texts (i.e. Margaret L. Cavendish Female Orations) bravely turned into a more confident voice claiming her rightful place in society (e.g. Mary Astell's A Serious Proposal to the Ladies Wherein a Method is offer'd for the Improvement of their Minds). Taillefer's historical route opens up to other European societies such as France, where the so-called Cahiers de doleances echoed the feminist contentions at the dawn of the French Revolution. Finally, this sequence of past events ends up with Mary Hays's and Perdita's writings in defense of the intellectual faculties of women, and for that purpose they make a general call to all men in Great Britain.

Each chapter is devoted to one of these women and to their writings, following a chronological order. All sections are headed by a historical introduction and a bibliography of each author; then, this contextualization is followed up by a translation of their writings, where they want to divulge their demands. The first to open this pioneering feminist saga is Margaret Tyrrell Tyler, a rather unknown character for the Spanish speaking reader in the history of feminism that Taillefer rescues from oblivion. Actually, Margaret Tyler carried out the first translation from Spanish of a chivalry romance, a literary genre that was considered frivolous and immoral by the Anglo-Saxon religious canons of the time. Tyler is followed by Rachel Speght, a contemporary poet who dared to publish texts with a religious and moralising intention, previously reserved to male hands.

In the same way, Priscilla Cotton and Mary Cole continued the moralistic aim of their predecessors, using in this case satiric texts with a strong sense of feminism and vindication. Their writings were addressed to both religious and laical men, being brave enough to even suggest a new interpretation of the Biblical word woman. Cotton and Cole belonged to the extremist religious sect of the Quakers, famous for encouraging the academic formation of women at the time. This religious denomination took in many other dames, whose names and works have been now brought to the feminist scene for the first time in Spain. Margaret Askew Fell Fox is another instance of feminine defense through a deep Quaker ideology, whose efforts and achievements were always veiled by those of her husband, George Fox, who was one of the founders of Quakerism. Augustus C. Bickley (2008: 1) analyses in depth the ideological grounds of this organisation in his recent book George Fox and the Early Quakers, where he defines this religious sect as a powerful "social movement". In this case, Lidia Taillefer goes beyond Bickley's historical appreciation of the issue and she offers the not 
less important educating task of these religious congregations by introducing Margaret A. Fell's modern religious theories.

This female collection of seventeenth-century religious figures is balanced with outstanding personalities in the fields of Arts and Education. However, despite their innovative contributions to the learning of foreign languages and to other academic disciplines, most of historical studies have not given them the recognition they deserve. Margaret Lucas Cavendish — Duchess of Newcastle - and Bathsua Reynolds Makin are relevant instances of educated women who were into the world of Linguistics and Translation. Cavendish's aristocratic circles drove her into the learning of typical feminine accomplishments, something that aroused her instinct of equality between genders. On the other hand, Bathsua Reynolds enjoyed a profound scholarly atmosphere at home thanks to her father's professional position; Reynolds exchanged letters with the famous Dutch intellectual Anna von Schurman, also interested in educating women and in providing means to do so. It is in these personal letters included in this volume where we can find another innovative point of this publication: while former collections present different literary genres, preferably poetry, this work focuses on genres traditionally considered less canonical (letters, diaries, memoirs and essays), therefore exploring the topic of women rights in a more explicit and intimate way.

Surprisingly, the private tone found in these women's personal letters is so carefully dealt with that readers feel as part of that feminist struggle. In the second half of the book, we come up with Mary Astell, one of the touchstones in the history of English feminism. She strongly vindicated the fact that God had created all human beings equal, and her focus is not only religious but it also includes a groundbreaking humanistic point of view. Taillefer's voice, as well as the feminist vindication itself, turns more intimate with her and also with Elizabeth Carter and Lady Mary Montagu. In these cases, their feminine campaign was carried out in a more domestic sphere, and this is what these authors present: a collection of personal and familial letters which have been translated into Spanish for the first time. This priceless compilation immerses the reader in the female life of the eighteenth century in England, while its inward mood evidences once more the novelty of this book.

Spanish readers did not have access to the most popular feminist texts since the publication of Amalia Martín-Gamero's Antología del feminismo, issued back in 1975. However, and picking up the innovative character of the volume mentioned above, Taillefer treats many more new British authors from the sixteenth, seventeenth and eighteenth centuries, whose writings are for the most part essays. On the other hand, in the field of literature in the English language, Clare Brant (2006) plunged us into the world of personal correspondence in her book Eighteenth-Century Letters and British Culture. The volume Origenes del feminismo comes then to combine a well-documented feminist research together with a pioneering lens to look closer at women at that time through their personal writings, what gives an engaging tone to the whole publication. Moreover, it brings to the reader's mind the unprecedented information offered in Taillefer's “Aportaciones de las mujeres a la lengua inglesa" (2007a), this time extended and contextualised in other historical fields, not only the linguistic one.

Some of the names that Taillefer presents in her publication belonged to the social feminist circle known as the Bluestockings, a group of middle-class and high-class women who openly vindicated their rights. In opposition to that personal attitude found in their correspondence, members of the circle and authors of great standing such as Catherine 
Graham, Ann Radcliffe and Mary Wollstonecraft dared to go into political, historical and metaphysical issues, always viewed as male fields. This literary panorama completes the one depicted by Sylvia H. Myers in 1990, in her book The Bluestocking Circle: Women, Friendship and the Life of the Mind in Eighteenth-Century England. Only a few references of this feminist club have been published in Spain, and the most recent are also to be found in a volume published by Taillefer in 2007c, Avanzando hacia la igualdad en las humanidades.

Orígenes del feminismo assembles a significant amount of female names that made a living on their novels, poetry and essays, something unusual for women at that time. Ann Radcliffe, Mary Hays and Maria Edgeworth, among others, are some of the ones who achieved acknowledgement for their writings, either receiving a positive or a negative appraisal. Other feminine colleagues worked and published several translations of literary and political pieces from different European languages into English, something already explored by this author back in 1995 in her article "Traductoras inglesas del Renacimiento", and that now seems to be the prelude to this book which starts in the sixteenth century. These representatives of the weaker sex bore out their intellectual superiority while challenging the patriarchal system of the age. In this new travel through the beginnings of feminism, Lidia Taillefer brilliantly offers sufficient evidence of the birth and growth of this sociological movement. Her data are supported by outstanding names and works in the field, such as the preface to the translation of Diego Ortúñez de Calahorra's Espejos de principes y caballeros, and - closing this magnificent recollection - the famous letter written by Mary Darby Robinson ('Perdita') in 1799, preventing all English women from feminine mental subordination.

At the end of this manual, the author has included a detailed bibliography split up into two sections: primary sources on the one hand, and secondary references on the other. In other words, there we can find the citations of the original texts written in English together with secondary sources that have provided the necessary information to dash off the theoretical and historical parts that frame this feminist work; the general introduction at the beginning of the book and the authors' individual presentations in each chapter guide the reader along this chronologically structured way through the rise of feminism.

This volume is definitely necessary for researchers concerned with Women's Studies, since it shows some of the seeds that triggered the growth of the main British feminist movements that would spread throughout Europe. Most relevantly of all, this work is highly recommended for all those interested in this topic from any other perspective, paying attention to the most intimate side of the writings or to the public rebellions of women, with their pens as the main weapon. After reading this new and warm approach to the studies of gender, one wonders if we could enjoy a sequel with new feminist texts and disclosures from the last two centuries, offering again a refreshing view of the feminist tradition.

\section{References}

Bickley, Augustus C. (2008): George Fox and the Early Quakers. Massachusetts: BiblioBazaar. Brant, Clare (2006): Eighteenth-Century Letters and British Culture. Houndmills: Palgrave Macmillan.

Fields, Armond (2003): Katherine Dexter McCormick: pioneer for women's rights. London: Praeger. Martin-Gamero, Amalia (1975): Antología del feminismo. Madrid: Alianza Editorial. 
Myers, Sylvia H. (1990): The Bluestocking Circle: Women, Friendship and the Life of the Mind in Eighteenth-Century England. Oxford: Clarendon Press.

Newell, Stephanie and Audrey Gadzekpo (eds.)(2004): Selected Writings of a Pioneer West African Feminist. Nottingham: Trent Editions.

Taillefer de Haya, Lidia (1995): "Traductoras inglesas del Renacimiento". Hieronymus Complutensis 2: 61-65.

. (2007a): “Aportaciones de las mujeres a la lengua inglesa”. In M. A. Durán López, coord., Mujeres, simbolismo y vida: estudios sobre mujeres. Málaga: SPICUM, 267-78.

. (2007b): "Pioneras de la lingüística inglesa: traductoras, educadoras y lingüistas". In A. Medina Guerra, ed., Avanzando hacia la igualdad. Málaga: Diputación Provincial de Málaga y Asociación de Estudios Históricos sobre la Mujer, 36-51.

. (coord.)(2007c): Avanzando hacia la igualdad en las humanidades. Málaga: Diputación Provincial de Málaga y Asociación de Estudios Históricos sobre la Mujer.

Valle Ferrer, Norma (2006): The Story of Luisa Capetillo, a Pioneer Puerto Rican Feminist. New York \& Oxford: Peter Lang. 